\title{
Effect of waste cooking oil addition on ammonia emissions during the composting of dairy cattle manure
}

\author{
Kazutaka Kuroda $^{1, *}$, Akihiro Tanaka ${ }^{1}$, Kenichi Furuhashi ${ }^{2}$, and Naoki Fukuju ${ }^{1}$
}

* Corresponding Author: Kazutaka Kuroda Tel: +81-96-242-7625, Fax: +81-96-249-1002,

E-mail: tazuka@affrc.go.jp

'Division of Livestock Research, Kyushu Okinawa Agricultural Research Center National Agriculture and Food Research Organization, Koshi 861-1192, Japan

2Department of Biological and Environmental Engineering, Graduate School of Agricultural and Life Sciences, The University of Tokyo,

Tokyo 113-8657, Japan

ORCID

Kazutaka Kuroda

https://orcid.org/0000-0001-9019-1936 Akihiro Tanaka

https://orcid.org/0000-0002-7478-1773 Kenichi Furuhashi

https://orcid.org/0000-0003-1273-7221

Naoki Fukuju

https://orcid.org/0000-0003-0406-272X

Submitted Aug 3, 2021; Revised Oct 7, 2021; Accepted Nov 10, 2021
Objective: The objective of this study was to evaluate the effect of waste cooking oil (WCO) addition on ammonia $\left(\mathrm{NH}_{3}\right)$ emissions during the composting of dairy cattle manure under two aeration conditions.

Methods: The composting tests were conducted using the laboratory-scale composting apparatuses (14 L of inner volume). Three composting treatments (Control, WCO1.5, and WCO3, with WCO added at $0 \mathrm{wt} \%, 1.5 \mathrm{wt} \%$, and $3 \mathrm{wt} \%$ of manure, respectively) were performed in two composting tests: aeration rate during composting was changed from 0.55 to $0.45 \mathrm{~L} / \mathrm{min}$ in Test 1 , and fixed at $0.3 \mathrm{~L} / \mathrm{min}$ in Test 2, respectively. The $\mathrm{NH}_{3}$ emitted and nitrogen losses during the composting were analyzed, and the effect of the addition of WCO on $\mathrm{NH}_{3}$ emissions were evaluated.

Results: Both tests indicated that the composting mixture temperature increased while the weight and water content decreased with increasing WCO content of the composting mixtures. On the other hand, the $\mathrm{NH}_{3}$ emissions and nitrogen loss trends observed during composting in Tests 1 and 2 were different from each other. In Test $1, \mathrm{NH}_{3}$ emissions and nitrogen losses during composting increased with increasing WCO contents of the composting samples. Conversely, in Test 2 , they decreased as the WCO contents of the samples increased.

Conclusion: The WCO addition showed different effect on $\mathrm{NH}_{3}$ emissions during composting under two aeration conditions: the increase in WCO addition ratio increased the emissions under the higher aeration rate in Test 1 , and it decreased the emissions under the lower aeration rate in Test 2 . To obtain reduction of $\mathrm{NH}_{3}$ emissions by adding WCO with the addition ratio $\leq 3 \mathrm{wt} \%$ of the manure, aeration should be considered.

Keywords: Aeration Condition; Ammonia Emissions; Composting; Dairy Cattle Manure; Waste Cooking Oil

\section{INTRODUCTION}

Composting is the process of preparing compost from organic material, typically organic waste, for use as plant fertilizer. In Japan, composting is commonly used to recycle livestock manure [1-3]. During composting, microorganisms actively decompose and stabilize the organic matter in manure. The heat generated by decomposition dries the manure and kills pathogens, weed seeds, and parasite eggs. However, composting also emits environmentally harmful gases, such as malodorous compounds and greenhouse gases [4,5]. Among these, ammonia $\left(\mathrm{NH}_{3}\right)$ is emitted in large quantities, thereby increasing odor-related complaints from the communities around the composting facilities, and increasing the occurrence of global environmental pollution events, such as acid rain and soil acidification [6,7]. Additionally, nitrogen loss via $\mathrm{NH}_{3}$ emissions decreases the value of compost for use as a fertilizer. Therefore, reducing $\mathrm{NH}_{3}$ emissions is essential to ensure efficient composting of livestock manure. 
Substantial $\mathrm{NH}_{3}$ emissions during composting are typically attributed to a high ratio of nitrogen to biodegradable carbon sources in composting materials. Finstein and Morris [8] reported that $\mathrm{NH}_{3}$ was emitted during the composting of municipal solid waste with a carbon to nitrogen ratio (C/ $\mathrm{N}$ ratio) $<25$. However, the $\mathrm{C} / \mathrm{N}$ ratio of animal manure is typically $<20$, which indicates that composting of animal manure will produce more $\mathrm{NH}_{3}$ [9-11]. If additional biodegradable carbon sources are added to the composting material, the growth of microorganisms, and the assimilation of nitrogen by these microorganisms will be promoted, thereby reducing $\mathrm{NH}_{3}$ emissions. Therefore, many studies have examined the effects of adding carbon sources during the composting of nitrogen-rich materials, including animal manure, on $\mathrm{NH}_{3}$ emissions [11].

In recent years, several studies have reported lower $\mathrm{NH}_{3}$ emissions were observed after the addition of cooking oil (CO) or waste cooking oil (WCO) during composting of animal manure [12-14] and rabbit food (as a model of organic waste) [15]. The lipids in CO and WCO are easily degradable carbon sources for microorganisms, and these studies suggested that $\mathrm{NH}_{3}$ emissions from composting can be reduced by adding $\mathrm{CO}$ and WCO. However, this method has not been widely used in composting of animal manure in the practical composting facilities.

In this study, laboratory-scale composting tests of dairy cattle manure were conducted to obtain basic information on the use of adding WCO to reduce $\mathrm{NH}_{3}$ emissions. Additionally, the effect of aeration on the application of this method was assessed.

\section{MATERIALS AND METHODS}

\section{Materials for composting}

Dairy cattle manure was collected from a dairy farmer in Kikuchi, Kumamoto Pref., Japan, and transported to our research center $1 \mathrm{~d}$ prior to each composting test. A small amount of straw, used as bedding material in cattle stalls, was contaminated in the manure, was removed before the composting. Sawdust was purchased from a composting center (Koshi Bio X, Koshi, Japan) and WCO was obtained from Hayashi Sangyo Co. Ltd., Kumamoto, Japan.

\section{Composting tests}

Composting apparatus: The composting tests were conducted using laboratory-scale composting apparatus (Kaguyahime, Fujihira Kogyo Co. Ltd., Tokyo, Japan), as described in Kuroda et al [16] (Figure 1A). The main part of the apparatus was a stainless cylinder vessel with an effective capacity of approximately $14 \mathrm{~L}$, which was filled with composting mixture. Further details are given in Table 1. A thermocouple sensor rod, connected to a data logger (TR-7wf; T\&D Corporation, Matsumoto, Japan) was inserted into the mixture to record the temperature fluctuations during composting. The vessel was placed in an insulation case, and the mixture was aerated at specific flow rates, as described in Table 1 , from the bottom of the cylinder by an air pump. A cooling bottle, gas sampling port, and two gas-washing bottles with $\mathrm{NH}_{3}$-collecting liquid ( $6 \mathrm{~N} \mathrm{H}_{2} \mathrm{SO}_{4}$ solution) were connected to the exhaust tube.

Composting test conditions: Table 1 shows the parameters set for the composting tests. The mixtures used for composting were prepared with dairy cattle manure, sawdust, and WCO. Two composting tests (Tests 1 and 2) with different aeration conditions were conducted. In both tests, three treatments were used: Control, WCO1.5, and WCO3 with WCO added to the dairy cattle manure and sawdust mixture at weights of $0 \%, 1.5 \%$, and $3 \%$ of the manure, respectively; additionally, the composting period was set to $20 \mathrm{~d}$. In Test 1 , the aeration rate was set at $0.55 \mathrm{~L} / \mathrm{min}$ for the first $7 \mathrm{~d}$ of composting, corresponding to $\approx 37 \mathrm{~L} / \mathrm{min} / \mathrm{m}^{3}$ of the initial composting material, and was later decreased to $0.50 \mathrm{~L} / \mathrm{min}$

Table 1. Composting test parameters (Test 1 and Test 2)

\begin{tabular}{|c|c|c|c|c|c|}
\hline \multirow{2}{*}{ Tests } & \multirow{2}{*}{ Treatments } & \multicolumn{3}{|c|}{ Materials (kg) } & \multirow{2}{*}{ Initial mixtures $(\mathrm{kg})^{2}$} \\
\hline & & Manure $^{1)}$ & Sawdust $^{1)}$ & WCO & \\
\hline \multirow[t]{3}{*}{ Test 1} & Control & 9.00 & 1.80 & - & 10.00 \\
\hline & WC01.5 & 9.00 & 1.80 & $0.135(1.5)^{3)}$ & 10.125 \\
\hline & wC03 & 9.00 & 1.80 & $0.270(3.0)$ & 10.250 \\
\hline \multirow[t]{3}{*}{ Test 2} & Control & 9.30 & 1.55 & - & 10.00 \\
\hline & WC01.5 & 9.30 & 1.55 & $0.140(1.5)$ & 10.129 \\
\hline & wC03 & 9.30 & 1.55 & $0.279(3.0)$ & 10.257 \\
\hline
\end{tabular}

WCO, waste cooking oil.

1) The weight ratios of manure and sawdust (manure/sawdust) differed marginally in the two tests: 5/1 in Test 1 and 6/1 in Test 2.

2) The values in this column indicate the initial weights of the composting mixtures placed in the composting apparatuses. Considering added amounts of WCO, the weights in WC01.5 and WCO3 treatments were higher than that in Control.

3) The values in parentheses are weight \% of WCO to dairy manure.

* Aeration rate ( $\mathrm{L} / \mathrm{min}$ ) in Test 1 was changed during the composting period; 0.55 (day 0 to 7 ), 0.50 (day 7 to 14 ), and 0.45 (day 14 to 20 ), and it was fixed at 0.3 in Test 2. 

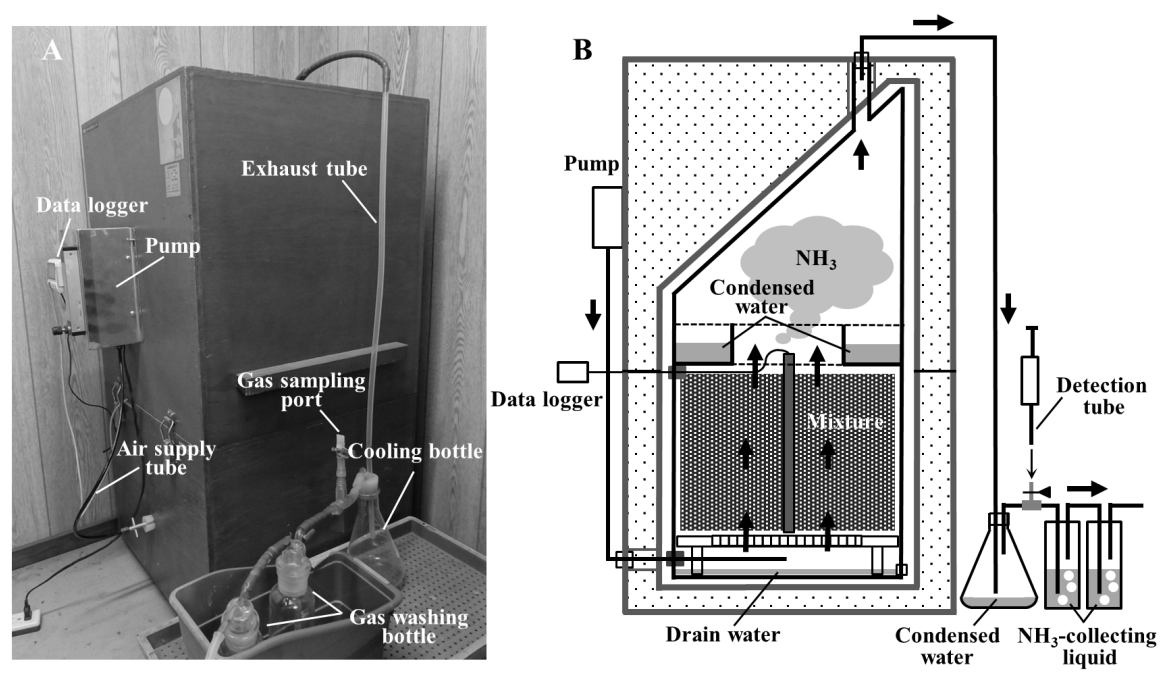

Figure 1. Composting apparatus: (A) photograph; (B) schematic view in use. Arrows indicate the flow of air.

( 7 to $14 \mathrm{~d}$ ) and $0.45 \mathrm{~L} / \mathrm{min}$ (14 to $20 \mathrm{~d}$ ). In Test 2 , the aeration rate was set at $0.30 \mathrm{~L} / \mathrm{min}$ throughout the composting process, corresponding to $\approx 23.4 \mathrm{~L} / \mathrm{min} / \mathrm{m}^{3}$ of the initial composting material. This aeration rate was substantially lower than that of large-scale composting treatments, which are typically 50 to $300 \mathrm{~L} / \mathrm{min} / \mathrm{m}^{3}$ of the composting material, and usually $\geq 100 \mathrm{~L} / \mathrm{min} / \mathrm{m}^{3}$ of the material [17]. Both tests were conducted in triplicates under the same parameters.

During composting, the $\mathrm{NH}_{3}$ concentration in the exhaust gas was measured using a detection tube (No. 3L or $3 \mathrm{M}$; Gastec Co., Ayase, Japan) at the gas sampling port at intervals of 12 or $24 \mathrm{~h}$. Water condensed outside the apparatus was retained in the cooling bottle and collected after every $\mathrm{NH}_{3}$ concentration measurement. The condensed water in the vessel was stored in the reservoir placed under the cap, and the drain water eluting from the mixture was retained at the bottom of the vessel (Figure 1B). On days 7 and 14, the mixture was removed from the apparatus, mixed completely, and returned to the apparatus (turning). In Test 1 , the aeration rate was changed after turning. Some amounts of the mixture were collected at the beginning and end of the composting. At the turnings and the end of the composting, the $\mathrm{NH}_{3}$-collecting liquid, condensed water, and drain water retained in the vessel were collected and used for further analyses.

\section{Sample analyses}

The mixtures and liquids collected during the composting tests were analyzed according to the methods described in Kuroda et al $[16,18]$. The water content, volatile solids (VS, an indicator of organic matter), and ash in the mixture were analyzed by drying the mixture at $105^{\circ} \mathrm{C}$ for $1 \mathrm{~d}$, followed by combustion at $550^{\circ} \mathrm{C}$ for $6 \mathrm{~h}$. For $\mathrm{pH}$ measurement, an extract of the mixture was prepared using a $2 \mathrm{~N} \mathrm{KCl}$ solution.

Ammonium nitrogen $\left(\mathrm{NH}_{4}-\mathrm{N}\right)$ and nitrous or nitric ni- trogen $\left(\mathrm{NO}_{\mathrm{x}}-\mathrm{N}\right)$ in the mixture were analyzed based on the methods of Bremner and Keeney [19], using a $2 \mathrm{~N} \mathrm{KCl}$ extract solution. Kjeldahl-nitrogen $(\mathrm{Kj}-\mathrm{N})$ in the mixture was analyzed according to the methods described in Kuroda et al [20] based on the method of Bremner [21]. Further, organic nitrogen and total nitrogen in the mixture were determined by subtracting $\mathrm{NH}_{4}-\mathrm{N}$ from $\mathrm{Kj}-\mathrm{N}$ and adding $\mathrm{Kj}-\mathrm{N}$ and $\mathrm{NO}_{\mathrm{x}}-\mathrm{N}$, respectively. The $\mathrm{NH}_{3}$-collecting liquid, condensed water, and drain water were mixed, and the dissolved $\mathrm{NH}_{4}-\mathrm{N}$ content was analyzed from this liquid mixture. The $\mathrm{NH}_{4}-\mathrm{N}$ content in the liquid mixture was determined as collected $\mathrm{NH}_{4}-\mathrm{N}$ during composting. The water content, VS, $\mathrm{pH}$, $\mathrm{NH}_{4}-\mathrm{N}$, and $\mathrm{NO}_{\mathrm{x}}-\mathrm{N}$ analyses were duplicated, and the $\mathrm{Kj}-\mathrm{N}$ analysis was quintuplicated for each sample. Based on these analyses, the total nitrogen composition of the initial and final mixtures and the nitrogen losses that occurred during composting were calculated and subjected to Tukey's test for assessing statistical significance.

\section{RESULTS}

\section{Composting test (Test 1)}

Changes in the temperatures of the composted mixtures and the $\mathrm{NH}_{3}$ concentrations in the exhaust gases during Test 1 are shown in Figure 2. During the first $14 \mathrm{~d}$ of composting, high temperatures were recorded for the mixtures with high WCO contents (Figure 2A). After the second turning on day 14 , the temperatures of all three mixtures remained below $41^{\circ} \mathrm{C}$. The $\mathrm{NH}_{3}$ concentrations increased considerably within the first $7 \mathrm{~d}$ of composting, and peaked within 2 to $4 \mathrm{~d}$. The peak $\mathrm{NH}_{3}$ mean concentration values were 693,655 , and 547 ppm for Control, WCO1.5, and WCO3 treatments, respectively. After the first turning, the $\mathrm{NH}_{3}$ concentrations of all three mixtures remained below 100 ppm (Figure 2B). 

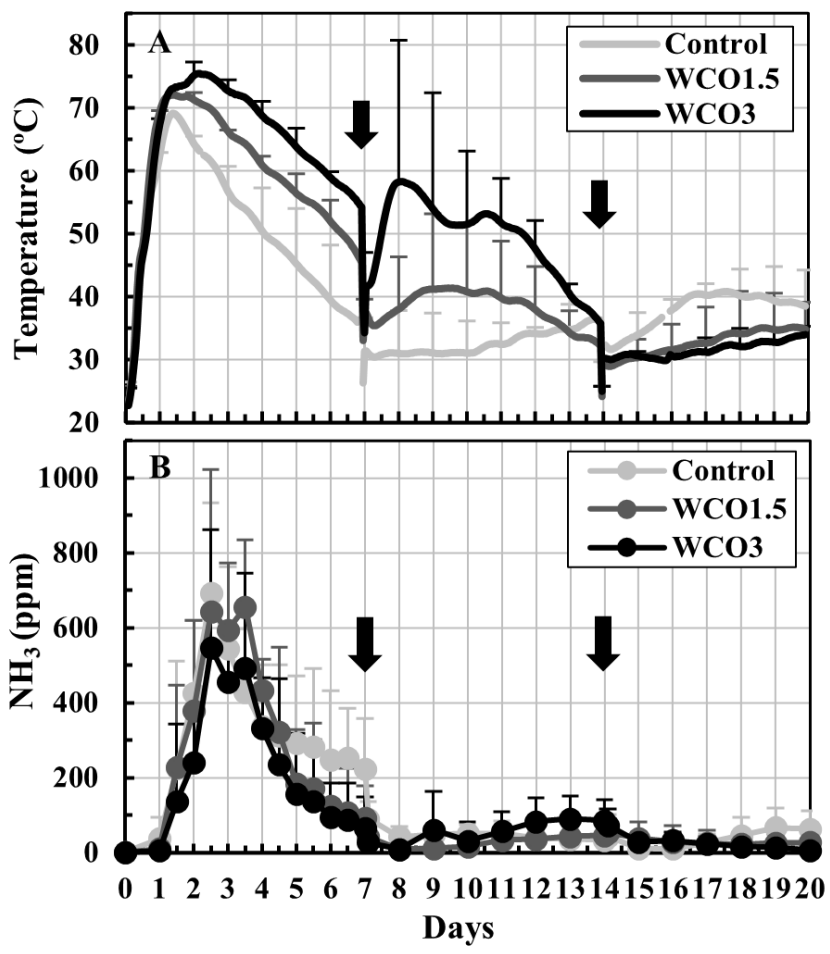

Figure 2. Changes in temperatures of the mixtures and $\mathrm{NH}_{3}$ concentrations in the exhaust gases during Test 1 . The means of the measured values at each measurement time point during repeated composting tests are plotted on the graphs. The bars on the lines indicate standard deviations $(n=3)$. The black ink density of the bar correspond to the respective treatments. The arrows indicate turning.
Table 2 shows the composition of the initial and final mixtures, the losses that occurred during composting, and $\mathrm{pH}$ values for Test 1 . The $\mathrm{pH}$ of the initial mixtures decreased with an increase in the WCO content, and the $\mathrm{pH}$ increased by the end of the test, reaching 8.3 to 8.7. At the beginning of composting, the VS content of the mixtures increased proportionally with the WCO content across the three treatments, whereas the water and ash contents were similar for all treatments. During composting, the total weights, water contents, and VS of the three mixtures decreased. The weights and water contents of the final mixtures decreased and the weight loss during composting increased with an increase in the WCO content. Significant differences $(\mathrm{p}<0.05)$ were observed between the total weights of the final mixtures in Control and WCO3 treatments, and between the water contents of the final mixtures and weight losses of all three treatments. However, composting did not affect the ash content in any of the treatments. The condensed water and drain water collected during composting accounted for $65 \%$ to $70 \%$ of the weight losses in the treatments. Moreover, the amount of condensed water increased with an increase in the WCO content, and significant differences $(\mathrm{p}<0.05)$ were observed between the condensed water amounts in Control treatment and those in WCO1.5 and WCO3.

The total nitrogen and the respective forms of nitrogen in the initial mixtures were similar for all samples. During com-

Table 2. Changes in the contents and pH of the composting mixtures in Test 1

\begin{tabular}{|c|c|c|c|c|c|c|}
\hline \multirow{2}{*}{ Items } & \multicolumn{3}{|c|}{ Initial mixture } & \multicolumn{3}{|c|}{ Final mixture } \\
\hline & Control & Wc01.5 & WCO3 & Control & WC01.5 & WCO3 \\
\hline $\mathrm{pH}$ & $7.34 \pm 0.26$ & $7.18 \pm 0.09$ & $7.07 \pm 0.07$ & $8.72 \pm 0.26$ & $8.42 \pm 0.41$ & $8.33 \pm 0.44$ \\
\hline Total weight (kg) & 10.000 & 10.125 & 10.250 & $8.59 \pm 0.18^{a}$ & $8.22 \pm 0.25^{\mathrm{ab}}$ & $7.76 \pm 0.11^{b}$ \\
\hline Water & $7.32 \pm 0.09$ & $7.36 \pm 0.11$ & $7.39 \pm 0.14$ & $6.44 \pm 0.26^{a}$ & $5.98 \pm 0.27^{b}$ & $5.49 \pm 0.20^{\circ}$ \\
\hline VS & $2.48 \pm 0.11$ & $2.58 \pm 0.11$ & $2.68 \pm 0.13$ & $1.95 \pm 0.10$ & $2.04 \pm 0.06$ & $2.07 \pm 0.15$ \\
\hline Ash & $0.20 \pm 0.02$ & $0.19 \pm 0.01$ & $0.18 \pm 0.01$ & $0.20 \pm 0.02$ & $0.20 \pm 0.02$ & $0.20 \pm 0.02$ \\
\hline Weight loss $(\mathrm{kg})$ & - & - & - & $1.41 \pm 0.18^{a}$ & $1.91 \pm 0.25^{b}$ & $2.49 \pm 0.11^{c}$ \\
\hline Condensed water ${ }^{1)}$ & - & - & - & $0.86 \pm 0.15^{a}$ & $1.28 \pm 0.19^{b}$ & $1.67 \pm 0.15^{b}$ \\
\hline Drain water ${ }^{2)}$ & - & - & - & $0.05 \pm 0.01$ & $0.04 \pm 0.01$ & $0.06 \pm 0.02$ \\
\hline Loss at turnings ${ }^{3)}$ & - & - & - & $0.08 \pm 0.03$ & $0.08 \pm 0.02$ & $0.10 \pm 0.03$ \\
\hline Other loss & - & - & - & $0.42 \pm 0.07^{a}$ & $0.50 \pm 0.09^{\mathrm{ab}}$ & $0.67 \pm 0.09^{b}$ \\
\hline Total nitrogen (g) & $40.56 \pm 0.98$ & $40.57 \pm 1.51$ & $40.62 \pm 0.88$ & $36.17 \pm 0.98$ & $35.16 \pm 0.18$ & $34.84 \pm 0.59$ \\
\hline Organic nitrogen & $29.05 \pm 1.32$ & $28.47 \pm 1.39$ & $28.26 \pm 0.95$ & $31.79 \pm 1.66$ & $31.69 \pm 1.63$ & $31.99 \pm 0.79$ \\
\hline $\mathrm{NH}_{4}-\mathrm{N}$ & $11.45 \pm 1.32$ & $11.91 \pm 0.75$ & $12.30 \pm 1.35$ & $4.35 \pm 2.36$ & $3.44 \pm 1.81$ & $2.49 \pm 0.65$ \\
\hline $\mathrm{NO}_{x}-\mathrm{N}$ & $0.06 \pm 0.06$ & $0.19 \pm 0.17$ & $0.06 \pm 0.10$ & $0.01 \pm 0.01$ & $0.03 \pm 0.05$ & $0.02 \pm 0.04$ \\
\hline Nitrogen loss (g) & - & - & - & $4.39 \pm 0.30$ & $5.41 \pm 1.33$ & $5.78 \pm 0.65$ \\
\hline Collected $\mathrm{NH}_{4}-\mathrm{N}^{4)}$ & - & - & - & $3.94 \pm 0.21$ & $4.88 \pm 1.30$ & $5.10 \pm 0.62$ \\
\hline Other loss & - & - & - & $0.45 \pm 0.08^{a}$ & $0.53 \pm 0.06^{\mathrm{ab}}$ & $0.69 \pm 0.05^{b}$ \\
\hline
\end{tabular}

Data are shown as means \pm standard daviations of the repeated composting test $(n=3)$.

VS, volatile solids; $\mathrm{NH}_{4}-\mathrm{N}$, ammonium nitrogen; $\mathrm{NO}_{x}-\mathrm{N}$, nitrous or nitric nitrogen.

1) Total value of condensed water collected from the inside and outside the composting apparatus.

2) Total value of drain water collected from inside the vessel.

3) Total value of weight losses at turnings.

${ }^{4)}$ Total value of $\mathrm{NH}_{4}-\mathrm{N}$ in the liquid samples (condensed water, drain water, and $\mathrm{NH}_{3}$-collecting liquid).

${ }^{a-c}$ The different characters following the values indicate significant differences $(p<0.05)$ between the values in the same issues. 
posting, $\mathrm{NH}_{4}-\mathrm{N}$ and total nitrogen in the mixtures decreased and the nitrogen losses increased in Control treatment, followed by WCO1.5 and WCO3. Compared with the initial mixtures, the organic nitrogen content in the final mixtures increased marginally in all three treatments. Further, less than $0.2 \mathrm{~g}$ of $\mathrm{NO}_{\mathrm{x}}-\mathrm{N}$ was detected in the three mixtures at the beginning and end of the tests. The collected $\mathrm{NH}_{4}-\mathrm{N}$ accounted for $88 \%$ to $90 \%$ of nitrogen losses in the treatments, and a significant difference was observed between the nitrogen losses except the collected $\mathrm{NH}_{4}-\mathrm{N}$ ("Other loss" in Table 2 ) in Control and $\mathrm{WCO} 3$ treatments. The average ratios of nitrogen losses to the total nitrogen contents in the initial mixtures were $15.2 \%, 19.2 \%$, and $21.7 \%$ in Control, WCO1.5, and $\mathrm{WCO} 3$ treatments, respectively. These ratios were approximately $26 \%$ higher in WCO1.5 and $43 \%$ higher in WCO3 than in Control.

\section{Composting test (Test 2)}

The trends of changes in temperatures of the composted mixtures and $\mathrm{NH}_{3}$ concentrations in the exhaust gases observed in Test 2 were similar to those in Test 1 (Figure 3). During the first $14 \mathrm{~d}$ of the test, high temperatures were recorded in the samples having high WCO contents (Figure 3A). Con-

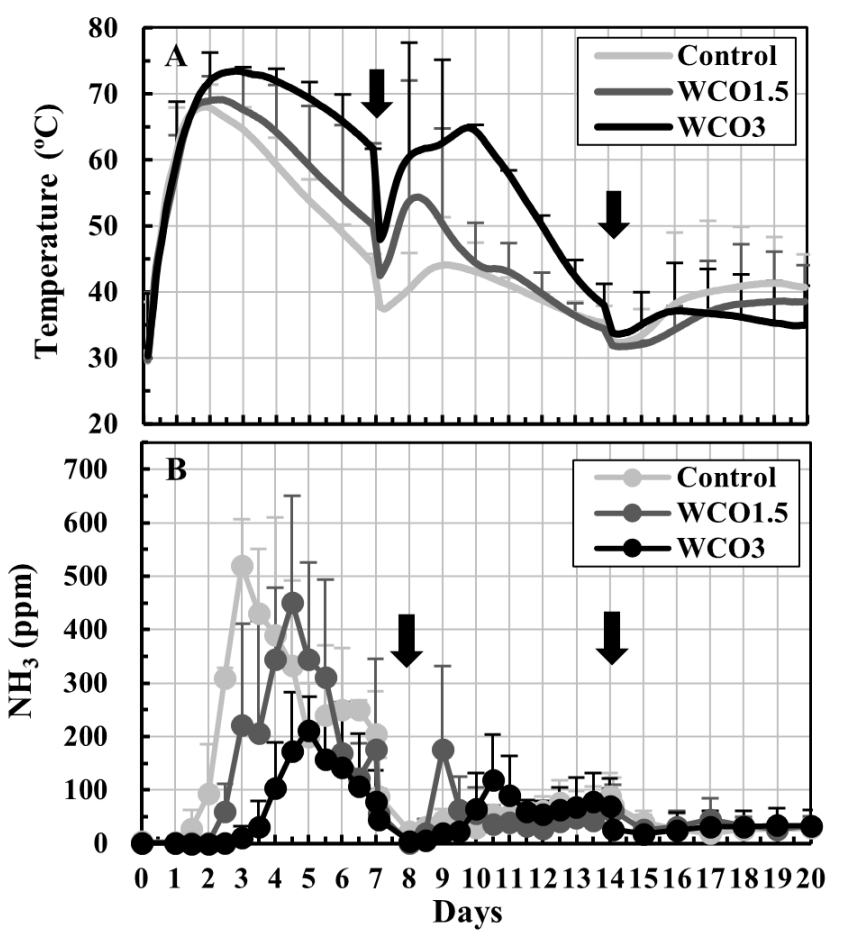

Figure 3. Changes in temperatures of the mixtures and $\mathrm{NH}_{3}$ concentrations in the exhaust gases during Test 2. The means of the measured values at each measurement time point during repeated composting tests are plotted on the graphs. The bars on the lines indicate standard deviations $(n=3)$. The black ink density of the bar correspond to the respective treatments. The arrows indicate turnings. siderable increases in the $\mathrm{NH}_{3}$ concentrations were observed in the first $7 \mathrm{~d}$, and the concentrations peaked 3 to $5 \mathrm{~d}$ from the beginning of the test and occurred slightly later than in Test 1 . The peak $\mathrm{NH}_{3}$ mean concentrations for Control, WCO1.5, and WCO3 treatments were 520, 450, and 212 ppm, respectively (Figure 3B).

Changes in the $\mathrm{pH}$ and the primary composition of the mixtures during composting were similar to those in Test 1 (Table 3). The initial $\mathrm{pH}$, which were low in the mixtures having a high WCO content, increased to 8.6 to 8.7 during composting. In the initial mixtures, the water and ash contents were the same for all samples, and the VS contents increased proportionally with the WCO content. Moreover, the total weights and water contents of the final mixtures decreased, and significant weight losses were observed, with increasing WCO contents. Significant differences $(\mathrm{p}<0.05)$ were observed between the weights of Control and $\mathrm{WCO} 3$ samples, and between the water contents and weight losses of samples of all three treatments. However, the ash contents in the treatments remained unaffected by composting. The condensed water and drain water accounted for $68 \%$ to $78 \%$ of the weight losses during composting in the three treatments. Moreover, the condensed water increased with increasing WCO content, with significant differences $(\mathrm{p}<0.05)$ observed between those in Control and those in WCO1.5 and WCO3.

The total nitrogen and the respective forms of nitrogen in the initial mixtures were similar for all samples. Furthermore, increases in the WCO content of the mixtures decreased the nitrogen loss and $\mathrm{NH}_{4}-\mathrm{N}$ content of the mixtures during composting. By the end of the composting, the organic nitrogen content of the mixtures marginally increased, while $\mathrm{NO}_{\mathrm{x}}-\mathrm{N}$ contents $(\leq 0.07 \mathrm{~g})$ remained unchanged in all three treatments, which was similar to the observations of Test 1. The collected $\mathrm{NH}_{4}-\mathrm{N}$ accounted for $89 \%$ to $91 \%$ of the nitrogen losses in the treatments. Moreover, significant differences $(p<0.05)$ were observed in the nitrogen losses and the collected $\mathrm{NH}_{4}-\mathrm{N}$ of the WCO3 and Control treatments. The average ratios of the nitrogen losses to the total nitrogen contents in the initial mixtures were $12.3 \%, 11.0 \%$, and $9.4 \%$ in Control, WCO1.5, and WCO3 treatments, respectively, and these ratios were approximately $11 \%$ and $24 \%$ lower in WCO1.5 and WCO3 treatments, respectively, than in Control.

Figure 4 shows the correlations between the WCO addition ratio ( 0 to $3 \mathrm{wt} \%$ of the manure) and weight and nitrogen losses of composted mixture during composting in Tests 1 and 2. Between the addition ratio and weight loss, positive linear correlations were observed in both tests (Figure 4A). On the other hand, a positive linear correlation between the WCO content and the nitrogen losses in Test 1 and a negative linear correlation between the two parameters in Test 2 (Figure 4B). 
Table 3. Changes in the contents and pH of the composting mixtures in Test 2

\begin{tabular}{|c|c|c|c|c|c|c|}
\hline \multirow{2}{*}{ Items } & \multicolumn{3}{|c|}{ Initial mixture } & \multicolumn{3}{|c|}{ Final mixture } \\
\hline & Control & WC01.5 & wCO3 & Control & WC01.5 & WCO3 \\
\hline $\mathrm{pH}$ & $7.57 \pm 0.09$ & $7.41 \pm 0.21$ & $7.07 \pm 0.26$ & $8.63 \pm 0.22$ & $8.66 \pm 0.17$ & $8.67 \pm 0.17$ \\
\hline Total weight (kg) & 10.000 & 10.129 & 10.257 & $8.77 \pm 0.11^{\mathrm{a}}$ & $8.36 \pm 0.13^{\mathrm{ab}}$ & $8.15 \pm 0.15^{b}$ \\
\hline Water & $7.40 \pm 0.12$ & $7.42 \pm 0.17$ & $7.43 \pm 0.17$ & $6.65 \pm 0.06^{a}$ & $6.27 \pm 0.13^{b}$ & $6.00 \pm 0.08^{c}$ \\
\hline VS & $2.38 \pm 0.12$ & $2.51 \pm 1.25$ & $2.62 \pm 0.17$ & $1.90 \pm 0.10$ & $1.89 \pm 0.02$ & $1.97 \pm 0.09$ \\
\hline Ash & $0.22 \pm 0.02$ & $0.20 \pm 0.05$ & $0.21 \pm 0.04$ & $0.22 \pm 0.03$ & $0.21 \pm 0.02$ & $0.22 \pm 0.03$ \\
\hline Weight loss (kg) & - & - & - & $1.23 \pm 0.11^{\mathrm{a}}$ & $1.77 \pm 0.13^{b}$ & $2.11 \pm 0.15^{\mathrm{c}}$ \\
\hline Condensed water ${ }^{1)}$ & - & - & - & $0.77 \pm 0.07^{\mathrm{a}}$ & $1.27 \pm 0.04^{b}$ & $1.42 \pm 0.32^{b}$ \\
\hline Drain water ${ }^{2)}$ & - & - & - & $0.06 \pm 0.06$ & $0.10 \pm 0.09$ & $0.16 \pm 0.16$ \\
\hline Loss at turnings ${ }^{3)}$ & - & - & - & $0.09 \pm 0.01$ & $0.12 \pm 0.03$ & $0.15 \pm 0.03$ \\
\hline Other loss & - & - & - & $0.42 \pm 0.07$ & $0.50 \pm 0.09$ & $0.67 \pm 0.09$ \\
\hline Total nitrogen (g) & $40.40 \pm 0.68$ & $40.24 \pm 0.88$ & $40.18 \pm 0.78$ & $35.44 \pm 0.53$ & $35.81 \pm 0.80$ & $36.41 \pm 1.13$ \\
\hline Organic nitrogen & $27.56 \pm 1.11$ & $26.64 \pm 0.23$ & $26.77 \pm 0.64$ & $29.94 \pm 1.15$ & $31.03 \pm 0.38$ & $31.88 \pm 0.79$ \\
\hline $\mathrm{NH}_{4}-\mathrm{N}$ & $12.77 \pm 0.75$ & $13.59 \pm 1.04$ & $13.41 \pm 0.75$ & $5.47 \pm 1.04$ & $4.77 \pm 1.16$ & $4.52 \pm 1.10$ \\
\hline $\mathrm{NO}_{x}-\mathrm{N}$ & $0.07 \pm 0.09$ & $0.02 \pm 0.03$ & $0.01 \pm 0.02$ & $0.03 \pm 0.05$ & $0.01 \pm 0.02$ & $0.01 \pm 0.03$ \\
\hline Nitrogen loss (g) & - & - & - & $4.95 \pm 0.48^{a}$ & $4.43 \pm 0.24^{\mathrm{ab}}$ & $3.78 \pm 0.44^{b}$ \\
\hline Collected $\mathrm{NH}_{4}-\mathrm{N}^{4)}$ & - & - & - & $4.44 \pm 0.39^{a}$ & $3.96 \pm 0.18^{\mathrm{ab}}$ & $3.44 \pm 0.48^{b}$ \\
\hline Other loss & - & - & - & $0.51 \pm 0.10$ & $0.47 \pm 0.07$ & $0.34 \pm 0.12$ \\
\hline
\end{tabular}

Data are shown as means \pm standard deviations of the repeated composting test $(n=3)$.

VS, volatile solids; $\mathrm{NH}_{4}-\mathrm{N}$, ammonium nitrogen; $\mathrm{NO}_{x}-\mathrm{N}$, nitrous or nitric nitrogen.

1) Total value of condensed water collected from the inside and outside the composting apparatus.

2) Total value of drain water collected from inside the vessel.

3) Total value of weight losses at turnings.

4) Total value of $\mathrm{NH}_{4}-\mathrm{N}$ in the liquid samples (condensed water, drain water, and $\mathrm{NH}_{3}$-collecting liquid).

${ }^{a-c}$ The different characters following the values indicate significant differences $(p<0.05)$ between the values in the same issues.

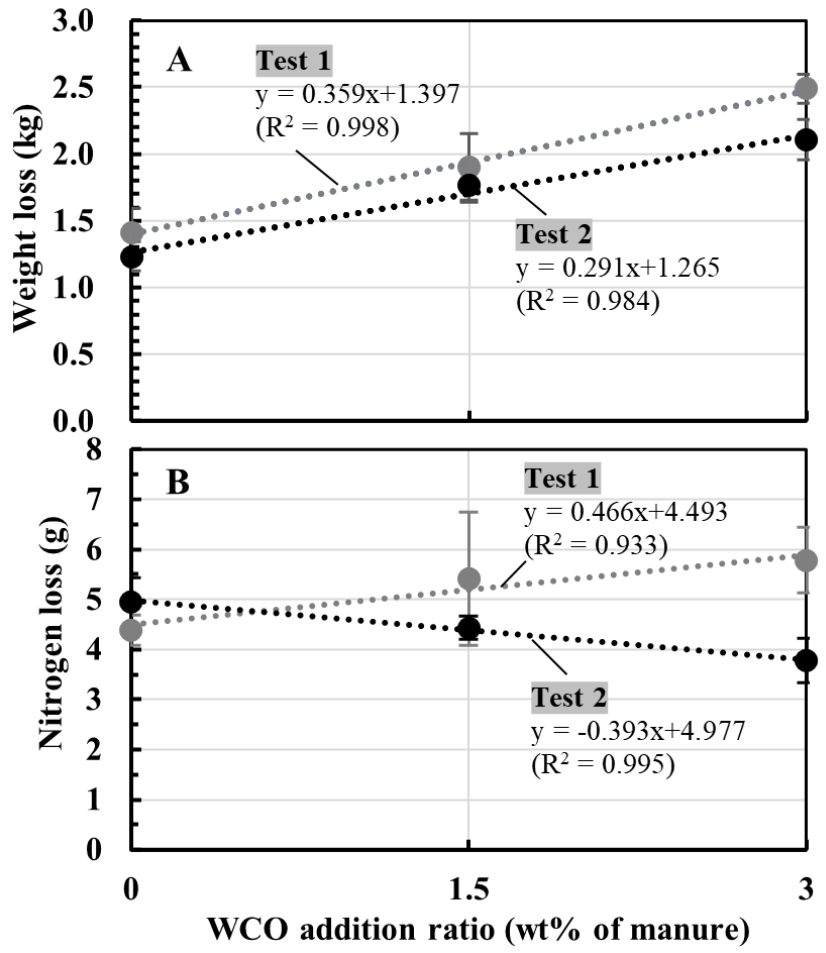

Figure 4. Relations between the WCO addition ratio and the losses of weight and nitrogen of the composted mixtures in Tests 1 and 2. Plotted values of the losses are the average values, and bars on the symbols are standard deviations (shown in Tables 2 and 3).

\section{DISCUSSION}

WCO is both an organic waste product and a recycling resource. In Japan, the annual WCO production in 2017 was 520,000 to 540,000 tons, of which approximately 390,000 to 430,000 tons were recycled to create various products, including livestock feed, ink, paint, soap, and fuel; however, the remainder WCO was incinerated or disposed in landfills $[22,23]$. Utilization in the composting treatment of animal manure might promote recycle use of WCO.

In both tests in this study (Tests 1 and 2), significant reductions in the total weight and water content of the composted mixtures were observed with increasing WCO contents (Tables 2, 3; Figure 4A). Several studies have investigated the effects of adding WCO or waste white clay, both of which are characterized by high lipid contents, on the composting of organic wastes; subsequently, accelerated drying and reduction of total weight of composted materials were observed [24-26]. These observations indicated that WCO addition promoted weight reduction of the composted material during composting under the wide range of aeration condition.

Conversely, the $\mathrm{NH}_{3}$ emissions and nitrogen loss trends observed during composting in Tests 1 and 2 differed from each other. In both tests, the collected $\mathrm{NH}_{4}-\mathrm{N}$ accounted for approximately $90 \%$ of the total nitrogen losses for all sam- 
ples, with some unavoidable nitrogen losses observed during the turnings (Tables 2, 3). Hence, $\mathrm{NH}_{3}$ emissions were responsible for most of the nitrogen losses during composting. In Test $1, \mathrm{NH}_{3}$ concentrations within the first $7 \mathrm{~d}$ of composting decreased marginally in WCO1.5 and WCO3 treatments compared with those in Control (Figure 2B); however, the collected $\mathrm{NH}_{4}-\mathrm{N}$ and nitrogen losses increased with increasing WCO contents (Table 2; Figure 4B). The inconsistency between these results could be because of deviations between the measured and actual $\mathrm{NH}_{3}$ concentrations that occurred probably due to intermittent measurements. Moreover, the dissolution of larger amounts of emitted $\mathrm{NH}_{3}$ in the larger condensed water in the WCO-added treatments than in Control, prior to measurement at the gas sampling port of the experimental system (Figure 1), may have caused the inconsistencies. Conversely, in Test $2, \mathrm{NH}_{3}$ concentrations decreased within the first $7 \mathrm{~d}$ of composting in the WCOadded treatments (Figure 3B). Moreover, nitrogen losses and collected $\mathrm{NH}_{4}-\mathrm{N}$ amount decreased as the WCO content increased, and significant differences $(\mathrm{p}<0.05)$ were observed in the two parameters between $\mathrm{WCO} 3$ and Control samples (Table 3; Figure 4B). These results indicated that aeration in the composting mixtures influenced the impact of adding WCO on $\mathrm{NH}_{3}$ emissions during composting.

The addition of WCO in composting was expected to influence $\mathrm{NH}_{3}$ emissions owing to its characteristics or metabolic reaction of microorganisms. In both composting tests, organic nitrogen contents increased in all three treatments although the VS and total nitrogen contents decreased (Tables 2, 3) by the end of composting. The increase in organic nitrogen content was proportional to the WCO content and was more evident in the WCO-added treatments in Test 2 than in Test 1. During composting, microorganisms must have generated $\mathrm{NH}_{4}-\mathrm{N}$ during the decomposition of organic matter, while simultaneously assimilating $\mathrm{NH}_{4}-\mathrm{N}$ during the synthesis of new microbial cells, and used the added WCO for both reactions. In this study, the balances of these reactions might have differed between WCO-added treatments in Test 1 and Test 2, causing differences in the $\mathrm{NH}_{3}$ emissions between the tests. On the other hand, the addition of WCO decreased the $\mathrm{pH}$ of the initial mixtures (Tables 2, 3), and increased temperatures in WCO1.5 and WCO3 treatments (Figures 2A, $3 \mathrm{~A})$. The decrease in the $\mathrm{pH}$ might have restricted $\mathrm{NH}_{3}$ emissions in the early stage of composting, whereas the increased temperatures might have accelerated the emissions. However, these phenomena occurred in both Tests 1 and 2. The $\mathrm{pH}$ increased to 8.3 to 8.7 in all samples by the end of composting, and the $\mathrm{NH}_{4}-\mathrm{N}$ contents in the final mixtures were less in WCO1.5 and WCO3 treatments than in Control. These observations suggested that $\mathrm{pH}$ decrease and heat generation caused by the addition of WCO did not substantially contribute to the different $\mathrm{NH}_{3}$ emission trends observed in
Tests 1 and 2.

Previous studies on the effect of CO or WCO during composting reported reduced $\mathrm{NH}_{3}$ emissions even under high aeration rates $\left(\geq 35 \mathrm{~L} / \mathrm{min} / \mathrm{m}^{3}\right.$ of the composting material) $[12,13,15]$. In these studies, the contents of CO or WCO $(\geq 10$ $\mathrm{wt} \%$ of the composting material) exceeded the amounts used in this study ( $\leq 3 \mathrm{wt} \%$ of the manure). Conversely, Furuya et al [14] reported a significant reduction in $\mathrm{NH}_{3}$ emissions with the addition of $\mathrm{CO}$ in the composting of swine manure without forced aeration. In this report, the $\mathrm{CO}$ addition ratio was set to $3.7 \mathrm{wt} \%$ of the composting mixture of manure and sawdust, close to the WCO addition ratio in the present study. To obtain reduction of $\mathrm{NH}_{3}$ emissions by adding $\mathrm{WCO}$ at the addition ratio $\leq 3-4 \mathrm{wt} \%$ of the manure, aeration condition during composting should be considered, and composting under low aeration rate or without forced aeration might be effective.

Future studies can focus on assessing the effect of adding WCO in reducing $\mathrm{NH}_{3}$ emissions in the settings of WCO addition ratio and aeration rate in this study ( $\leq 3 \mathrm{wt} \%$ of the manure and $\approx 23 \mathrm{~L} / \mathrm{min} / \mathrm{m}^{3}$ of the material) in large-scale composting treatments in reducing $\mathrm{NH}_{3}$ emissions to explore the potential applications of this method. Additionally, the impact of WCO addition on the quality of the prepared compost should be examined.

\section{CONFLICT OF INTEREST}

We certify that there is no conflict of interest with any financial organization regarding the material discussed in the manuscript.

\section{FUNDING}

This study was supported by the Ministry of Agriculture, Forestry and Fisheries Japan, under the commissioned project studies of "Development of odor mitigation technology in the livestock sector (15650964)" and "Development of comprehensive malodor reduction and odor diffusion prevention technology (18065025)".

\section{ACKNOWLEDGMENTS}

We are thankful to Mr. Jiro Shimazaki, Mr. Hidenori Nagano, Mr. Yukinari Kawahara, Mr. Shigenori Fukumori, Ms. Hitomi Hisamatsu, and Ms. Sayoko Hirayama for their helpful assistance in this study.

\section{REFERENCES}

1. Haga K. Production of compost from organic wastes. ASPAC/ FFTC Ext Bull 1990;311:1-18. 
2. Harada Y. Composting and land application of animal wastes. Asian-Australas J Anim Sci 1992;5:113-21. https://doi.org/10. 5713/ajas. 1992.113

3. Haga K. Development of composting technology in animal waste treatment. Asian-Australas J Anim Sci 1999;12:604-6. https://doi.org/10.5713/ajas.1999.604

4. Kuroda K, Osada T, Yonaga M, et al. Emissions of malodorous compounds and greenhouse gases from composting swine feces. Bioresour Technol 1996;56:265-71. https://doi.org/10. 1016/0960-8524(96)00047-8

5. Fukumoto Y, Osada T, Hanajima D, Haga K. Patterns and quantities of $\mathrm{NH} 3, \mathrm{~N} 2 \mathrm{O}$ and $\mathrm{CH} 4$ emissions during swine manure composting without forced aeration-effect of compost pile scale. Bioresour Technol 2003;89:109-14. https:// doi.org/10.1016/S0960-8524(03)00060-9

6. Peigne J, Girardin P. Environmental impacts of farm-scale composting practices. Water Air Soil Pollut 2004;153:45-68. https://doi.org/10.1023/B:WATE.0000019932.04020.B6

7. Monteny GJ, Hartung E. Ammonia emissions in agriculture. Wageningen, The Netherlands: Wageningen Academic Publishers; 2007.

8. Finstein MS, Morris ML. Microbiology of municipal solid waste composting. Adv Appl Microbiol 1975;19:113-51. https:// doi.org/10.1016/S0065-2164(08)70427-1

9. Rynk R, van de Kamp M, Willson GB. et al. Characteristics of raw materials. In: Rynk R, editor. On-Farm composting handbook. Ithaca, NY, USA: Northeast Regional Agricultural Engineering Service; 1992. p. 106-13.

10. Maeda T, Matsuda J, Ohmiya K. Ammonia emissions from composting livestock manure (Part 2) -Effects on livestock type on ammonia emission during composting- (in Japanese). J Japan Soc Agric Machin 2001;63:41-7. Available from: https:// www.jstage.jst.go.jp/article/jsam1937/63/1/63_1_41/_pdf/char/ja

11. Bernal MP, Alburquerque JA, Moral R. Composting of animal manures and chemical criteria for compost maturity assessment. A review. Bioresour Technol 2009;100:5444-53. https:// doi.org/10.1016/j.biortech.2008.11.027

12. Ichikawa A, Nakatani H, Kato H, Kano M, Masuda T, Sugiyama $\mathrm{H}$. Effects of the waste cooking oil on composting of swine manure I: Effects of the additional amounts of the waste cooking oil (in Japanese). Res Bull Aichi Agric Res Ctr 1998; 30:313-6.

13. Takahashi M. Influence of addition of wastes cooking oil on the organic matter decomposition in dairy cattle manure compost (in Japanese). Anim Sci J 2006;77:433-42. https:// doi.org/10.2508/chikusan.77.433

14. Furuya M, Osada T, Ogino A, Shimizu K, Fukuzawa A. Patterns and Quantities of odor and greenhouse gas emissions from swine manure composting with addition of cooking oil or urea (in Japanese). J Anim Product Environ Sci 2017;16:5060. Available from: http://www.apesj.jpn.org/DL/Furuya 2017.pdf

15. Matsumura H, Sasaki M, Kato S, Nakasaki K. Unusual effects of triacylglycerol on the reduction of ammonia gas emission during thermophilic composting. Bioresour Technol 2010; 101:2300-5. https://doi.org/10.1016/j.biortech.2009.11.006

16. Kuroda K, Hanajima D, Fukumoto Y, et al. Isolation of thermophilic ammonium-tolerant bacterium and its application to reduce ammonia emission during composting of animal wastes. Biosci Biotechnol Biochem 2004;68:286-92. https:// doi.org/10.1271/bbb.68.286

17. Haga K. Composting treatment (in Japanese). In: Oshida T, Kakiichi N, Haga K, editors. New version of Environment Preservation for Animal Production. Tokyo, Japan: Yokendo Ltd. Publishers; 2012. p. 71-6.

18. Kuroda K, Waki M, Yasuda T, Fukumoto Y, Tanaka A, Nakasaki K. Utilization of Bacillus sp. strain TAT105 as a biological additive to reduce ammonia emissions during composting of swine feces. Biosci Biotechnol Biochem 2015;79:1702-11. https://doi.org/10.1080/09168451.2015.1042831

19. Bremner JM, Keeney DR. Steam distillation methods for determination of ammonium, nitrate and nitrite. Anal Chim Acta 1965;32:485-95. https://doi.org/10.1016/S0003-2670 (00)88973-4

20. Kuroda K, Tanaka A, Furuhashi K, Nakasaki K. Application of Bacillus sp. TAT105 to reduce ammonia emissions during pilot-scale composting of swine manure. Biosci Biotechnol Biochem 2017;81:2400-6. https://doi.org/10.1080/09168451. 2017.1389607

21. Bremner JM. Nitrogen-total, In: Sparks DL, Helmke PA, Loeppert RH, Soltanpour PN, Tabatabai MA, Johnston CT, Sumner ME, editors. Methods of soil analysis. Part 3 Chemical methods. Madison, WI, USA: American Society of Agronomy; 1996. p. 1085-121.

22. National Federation of Oil and Fat Business Cooperatives, Japan, editor. UC oil recycling guide (in Japanese) [Internet]. Tokyo, Japan: National Federation of Oil and Fat Business Cooperatives, Japan; 2007. Available from: http://www. zenyuren.or.jp/wp/wp-content/uploads/2017/12/ucoil_ tebiki.pdf

23. National Federation of Oil and Fat Business Cooperatives, Japan. Flow of UC oil recycling (2017 version) (in Japanese) [Internet]. Tokyo, Japan: National Federation of Oil and Fat Business Cooperatives, Japan; 2018. Available from: http:// www.zenyuren.or.jp/wp/wp-content/uploads/2018/11/180510 _ucoli_recycle_flow2017.pdf

24. Miyazaki T, Honda K, Yajima J. Continuous composting of cattle dung by composting machine IV. Effect of addition of abolition oil to cattle dung (in Japanese). Bull Kanagawa Pref Livest Exp Sta 1995;85:50-4.

25. Seki M, Oyanagi W. Effect of addition of waste cooking oil for composting of dairy cattle dung (in Japanese). Bull Niigata Anim Husb Exp Sta 1998;12:26-8. Available from: https:// 
www.pref.niigata.lg.jp/uploaded/attachment/220541.pdf

26. Fushinobu S. Characterization of lipid decomposing enzymes of the thermophilic bacteria and application to thermophilic fermentation system by adding used cooking oil (in Japanese). Project result report of the subsidy project of environment research and technology development fund fiscal year 2013. Environmental Restoration and Conservation Agency; 2014. Available from: https://www.env.go.jp/policy/kenkyu/suishin/ kadai/syuryo_report/h25/pdf/3K122014.pdf 